\title{
SEED PRIMING AND EXOGENOUS APPLICATION OF SALICYLIC ACID ENHANCE GROWTH AND PRODUCTIVITY OF OKRA (Abelmoschus esculentus L.) BY REGULATING PHOTOSYNTHETIC ATTRIBUTES
}

\author{
Mohammad Saidur Rhaman ${ }^{1 * \#(\mathbb{D}), \text { Farjana Rauf }}{ }^{1 \#}$, Shaila Shermin Tania ${ }^{1}$, \\ Md. Masudul Karim², Ashaduzzaman Sagar ${ }^{2}$, Arif Hasan Khan Robin ${ }^{3}$, \\ Arafat Abdel Hamed Abdel Latef ${ }^{4}$, Yoshiyuki Murata ${ }^{5}$
}

\footnotetext{
${ }^{1}$ Department of Seed Science and Technology, Bangladesh Agricultural University, Mymensingh-2202

${ }^{2}$ Department of Crop Botany, Bangladesh Agricultural University, Mymensingh-22023

${ }^{3}$ Department of Genetics and Plant Breeding, Bangladesh Agricultural University, Mymensingh-2202

${ }^{4}$ Botany and Microbiology Department, Faculty of Science, South Valley University, Qena 83523, Egypt

${ }^{5}$ Department of Bio-functional Chemistry, Okayama University, Okayama, Japan

${ }^{\#}$ Equal contribution
}

Received - October 26, 2021; Revision - December 09, 2021; Accepted - December 14, 2021

Available Online - December 30, 2021

DOI: http://dx.doi.org/10.18006/2021.9(6).759.769

\section{KEYWORDS \\ Chlorophyll contents \\ Hormonal priming \\ Photosynthesis \\ Seed priming \\ Salicylic acid}

\begin{abstract}
Low and uneven germination is a serious problem for the successful production of okra seedlings. Priming of seeds as well as supplementation of different plant growth regulators exhibited better response in successful seedling production which eventually results in higher yield. Therefore, the present study was conducted to evaluate the effects of seed priming and exogenous application of salicylic acid (SA) on okra seed germination and plant development. The okra seeds were primed by 1 $\mathrm{mM}$ and $2 \mathrm{mM}$ of SA for 60 minutes whereas the seeds were washed several times with distilled water for the control treatment. Similar doses of SA have been exogenously sprayed to the 12 days okra seedlings for 4 days. The results of the study revealed that seed priming with SA enhanced germination percentage (GP), increased coleoptile length and weight, shoot and root length, and seed vigor index (SVI). Similarly, exogenous application of $1 \mathrm{mM} \mathrm{SA}$ increased relative water content (RWC), contents of chlorophyll a, chlorophyll b, total chlorophyll while a higher dose of SA ( $2 \mathrm{mM})$ degraded the leaf pigments. Supplementation of SA altered photosynthetic attributes, net photosynthetic (Pn) and transpiration rate ( $\mathrm{Tr}$ ), stomatal conductance (Gs), and water use efficiency (WUE). Moreover, SA treatment reduced the time duration of flower bud initiation and days to first flowering and enhanced the
\end{abstract}

* Corresponding author

E-mail: saidursst@bau.edu.bd (Mohammad Saidur Rhaman)

Peer review under responsibility of Journal of Experimental Biology and Agricultural Sciences.

Production and Hosting by Horizon Publisher India [HPI] (http://www.horizonpublisherindia.in/).

All rights reserved.
All the articles published by Journal of Experimental Biology and Agricultural Sciences are licensed under a Creative Commons Attribution-NonCommercial 4.0 International License Based on a work at www.jebas.org.

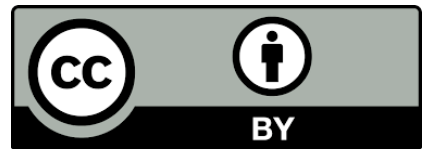


yield per plant. The results of this study indicated that seed priming and exogenous application of SA enhanced germination and okra productivity by regulating RWC and photosynthetic attributes where $1 \mathrm{mM} \mathrm{SA}$ is more effective compared to $2 \mathrm{mM} \mathrm{SA}$.

\section{Introduction}

Okra (Abelmoschus esculentus L.) is a widely-grown dicotyledonous plant and popular summer crop throughout the tropics (Tania et al., 2020; Elkhalifa et al., 2021) under the family of malvaceae. It is a familiar vegetable crop in many countries and also known as lady's fingers, or gumbo that grows up to 1.0-2.1 meters tall. The immature pod is the edible part of okra which is harvested at the tender stage. Okra is an important source of vitamins, $\mathrm{A}, \mathrm{C}$, and $\mathrm{K}$, and mineral salts including calcium (Gemede et al., 2015). However, successful okra production faces various problems due to certain factors like seed quality, climatic circumstances, and cultural operations (Kusvuran, 2012; Lamichhane et al., 2021). It has been reported that slow and uneven germination is the main hurdle in okra production due to the presence of hard seededness (Felipe et al., 2010; Pandita et al., 2010; Lamichhane et al., 2021). Also, the okra yield reduces due to the slow and erratic emergence of okra seedlings (Rahman et al., 2016). However, nowadays, researchers are concentrated on different approaches like seed priming, screening of best varieties, and organic fertilizer application, and exogenous applications of different plant growth regulators such as auxin, SA, abscisic acid, 5-aminolevulinic acid, citric acid, and so on to overcome this problem (Rhaman et al., 2016; Yakoubi et al., 2019; Abdel Latef et al., 2021; Rhaman et al., 2021a, b; Tahjib-Ul-Arif et al., 2021).

Supplementation of chemicals to plants, either as an exogenous foliar application or seed treatments, may prompt their physiological apparatuses, leading to plant growth enhancement (Vwioko, 2013). For instance, seed priming with plant growth regulators can bring changes in the phenotypes of plants from seed germination to senescence (Rhaman et al., 2021a). Salicylic acid (SA) is an endogenous growth regulator of phenolic nature, which influences a range of various progressions in plants such as seed germination and seedling growth, photosynthesis, and stomatal regulation (Khan et al., 2003; Prodhan et al., 2018; Koo et al., 2020). It has been reported that okra seeds priming with SA enhance the vegetative growth rate and leaf water contents of plants (Raza et al., 2013). Supplementation of SA increases the growth rate and photosynthesis of Rosmarinus officinalis plants (Najafian et al., 2009). In addition, the exogenous application of SA enhances the yield and yield contributing characters of Brassica juncea (Dugogi et al., 2012). Hussein (2015, 2017) reported that seed priming with SA enhances the viability of okra. Likewise, SA application enhances biochemical characteristics and plant developments of okra (Raza et al., 2013). In addition, supplementation of SA enhances the morphological parameters and growth rate of onion and soybean (Razmi et al., 2017; Bhasker et al., 2020).

Recently, many studies have been reported that seed priming is a promising technique that enhances seed germination and fastens plant growth under normal and as well as in stress conditions by regulating different physiological processes (Muhei, 2018; Hasanuzzaman \& Fotopoulos 2019; Rhaman et al., 2020). Similarly, many reports showed that supplementation of SA enhances the growth and yield of many plant species by regulating photosynthetic attributes (Tahjib-Ul-Arif et al., 2018; Gul et al., 2020). Though, some studies reported that SA priming of okra seeds enhances morphological parameters and yield of okra. However, the regulatory role of SA priming and exogenous application of SA on okra crop enhancement still remains unclear. Therefore, the present study was conducted to assess the effects of seed priming and the exogenous application of SA on okra production.

\section{Materials and Methods}

\subsection{Plant Materials and Chemicals}

The experiment was carried out at the Department of Seed Science and Technology of Bangladesh Agricultural University, Mymensingh, using BARI dharosh-2, a recently developed high yielding variety that is widely cultivated in many regions of Bangladesh. The BARI dharosh-2 is very soft, tasty, and produced fruit at every single node. The chemicals, SA (Sigma-Aldrich), sodium hypochlorite (Sigma-Aldrich), and Hyponex (Osaka, Japan) nutrient solution were used as an analytical grade in this study.

\subsection{Experiment at pre-seedling stage}

Uniform in appearance okra seeds were sorted out and surface sterilized with $1 \%$ sodium hypochlorite for $5 \mathrm{~min}$ and then washed 3-4 times with $\mathrm{dH}_{2} \mathrm{O}$. For the seed priming experiment, the seeds were soaked in $1 \mathrm{mM}$ and $2 \mathrm{mM}$ SA for 60 minutes, and the control experiment seeds were washed in distilled water for several times in a normal laboratory (the room temperature was $25 \pm 1^{\circ} \mathrm{C}$ and relative humidity was $95 \%$ ) conditions. After that, treated seeds were placed in a petri-dish $(150 \times 20 \mathrm{~mm}$ diameter $)$ having three layers of wetted-Whatman filter papers and incubated for 10 days for the germination study. Fifteen treated seeds were placed in each petri-dish. Thus there were three treatments in this study; 
control; 1mM SA, 2 mM SA. The experiment was conducted with a completely randomized block design having three replicates.

Morphological parameters, coleoptile length, and coleoptile weigh at the germination period were collected after the $10^{\text {th }}$ day Germination percentage (GP) and seed vigor index (Tania et al. 2020) were computed with the following equations:

Germination percentage $(\mathrm{GP})=$

$$
\begin{aligned}
& \frac{\text { Total number of seeds germinated }}{\text { Total number of seeds placed in germination }} \times 100 \\
& \text { Seed vigor index }(\mathrm{SVI})=\mathrm{GP} \times \text { seedling length }(\mathrm{cm})
\end{aligned}
$$

\subsection{Experiment at seedling stage}

Uniformly germinated seeds were placed in plastic pots $(22 \mathrm{~cm}$ in height and $25 \mathrm{~cm}$ in diameter) filled with soil (6 seedlings per pot). The soil is properly mixed with nutrient solution Hyponex (Osaka, Japan) containing nitrogen, phosphorous, potassium, and other micronutrients. The nutrient solution $(2 \mathrm{ml}$ mixed with water for per pot) was applied twice in a week in the pots. After 12 days, seedlings were exogenously treated with $1 \mathrm{mM}$ and $2 \mathrm{mM} \mathrm{SA}$ for four times in four days (single spray per day at $11 \mathrm{am} ; 8 \mathrm{ml}$ per plant per spray). After 4 days of SA treatment, morphological and physiological data were collected from three plants while several healthy plants from each pot were kept to record reproductive stage data and yield per plant.

\subsection{Relative water content measurement}

Relative water content (RWC) was determined followed by the standard procedure of Mostofa \& Fujita (2013). In the case of RWC measurement, leaf samples were collected after 21 days of planting and then fresh weight $(\mathrm{FW})$ of leaves were taken and immersed in $\mathrm{dH}_{2} \mathrm{O}$ and kept for $4 \mathrm{hr}$. After that, excess water was removed from the turgid leaves with a paper towel and turgid weight (TW) was recorded instantly. After that leaves were oven dried at $70{ }^{\circ} \mathrm{C}$ for $48 \mathrm{hrs}$ and dry weight (DW) was recorded. The RWC was calculated according to the following formula:

$$
\mathrm{RWC}(\%)=(\mathrm{FW}-\mathrm{DW}) /(\mathrm{TW}-\mathrm{DW}) \times 100
$$

\subsection{Estimation of photosynthetic and gas exchange parameters}

The net photosynthetic (Pn) and transpiration rate (Tr), stomatal conductance (Gs), were measured using a portable photosynthetic machine (LCi-SD System, ADC Bioscientific Ltd., Hoddesdon, UK) data were recorded from the fully expanded leaf at $11.00 \mathrm{am}$ to $2.00 \mathrm{pm}$. The measurements were performed at a 600 $700 \mu \mathrm{mol} \mathrm{mol}^{-1} \mathrm{CO}_{2}$ concentration, leaf temperature was $28^{\circ} \mathrm{C}$, and photosynthetic photon flux was $600-700 \mu \mathrm{mol} \mathrm{m}^{-2} \mathrm{~s}^{-1}$, the flow rate at $200 \mathrm{~mL} \mathrm{~min}^{-1}$, and the area inside the leaf chamber being at $5.8 \mathrm{~mm}^{3}$.

\subsection{Measurement of leaf chlorophyll contents}

The contents of photosynthetic leaf pigments chlorophyll a (Chl a), chlorophyll b ( Chl b), total chlorophyll, and carotenoids were determined spectro-photometrically based on the method described by Lichtenthaler (1987). For this, $0.5 \mathrm{~g}$ fresh leaves were collected into a small vial containing $10 \mathrm{~mL}$ of $80 \%$ acetone. The containers were covered by aluminum foil and preserved in the dark for 7 days for extraction of pigments. The absorbance was measured from leaf extraction at 663, 645, and $663 \mathrm{~nm}$ wavelength for $C h l a$, $C h l b$, and total chlorophyll contents by using a spectrophotometer (Shimadzu UV-2550, Kyoto, Japan). The Chl $a$, Chl b, total chlorophyll, and carotenoids contents were calculated using the following equations:

$$
\begin{gathered}
\text { Chlorophyll } \mathrm{a}=0.999 \times \mathrm{A} 663-0.0989 \times \mathrm{A} 645 \\
\text { Chlorophyll } \mathrm{b}=-0.328 \times \mathrm{A} 663+1.77 \times \mathrm{A} 645 \\
\text { Carotenoids }=480+(0.114 \times 663-0.638 \times 645)
\end{gathered}
$$

\subsection{Principal component analysis (PCA)}

To assess the relationship between the morpho-physiological traits and SA treatments, a PCA was performed using Minitab 17 statistical software

\subsection{Statistical Analysis}

Data collected for each parameter were subjected to one way ANOVA using Minitab 17 statistical software (Minitab Inc., State College, PA, USA). The statistical differences among the mean values of different treatments were compared using Tukey's pairwise comparisons $(\mathrm{P}<0.05)$.

\section{Results}

\subsection{Exogenously applied SA enhances seedling traits of Okra}

This study examined the effects of exogenous SA on seedling traits of okra. Data revealed that the growth traits of okra plants were significantly enhanced by SA treatment (Figure 1). Supplementation of $1 \mathrm{mM} \mathrm{SA}$ showed a significant increment in germination percentage (GP), coleoptile length (CL), coleoptile weight (CW), shoot length (SL), root length (RL), and seed vigor index (SVI) by $44.3,74.7,122.2,46.7,84.1$, and $131.6 \%$, respectively, over control (Figure 1), while $2 \mathrm{mM} \mathrm{SA}$ did not significantly increase the seedling traits. The germination percentage was higher in $1 \mathrm{mM}$ SA (86.6\%) compared with $2 \mathrm{mM}(70 \%)$ and control $(60 \%)$, respectively (Figure 1a). Similarly, coleoptile length $(6.31 \mathrm{~cm})$ and weight $(0.121 \mathrm{~g})$ were highest at $1 \mathrm{mM}$ concentration of SA (Figure $1 \mathrm{~b}, \mathrm{c}$ ). A similar trend was found in the shoot and root length, and seedling vigor index. These results indicate that supplementation of SA enhances the seedling traits of okra. 
(a)

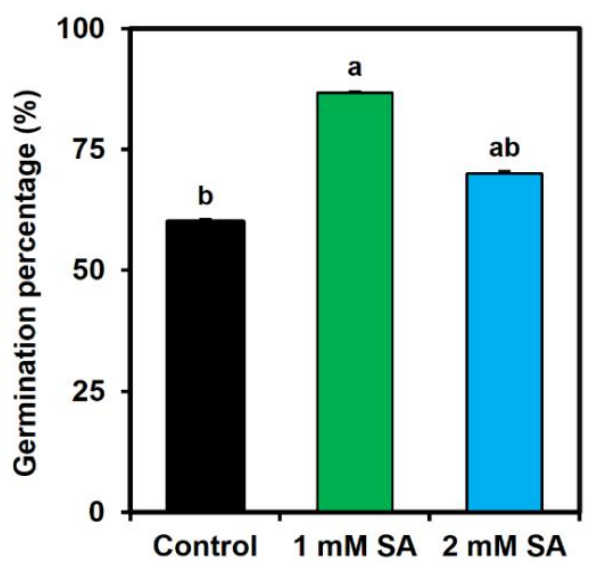

(c)

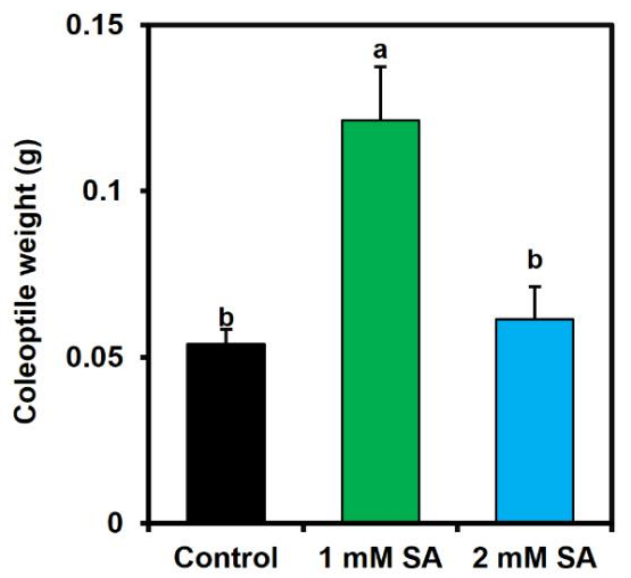

(e)

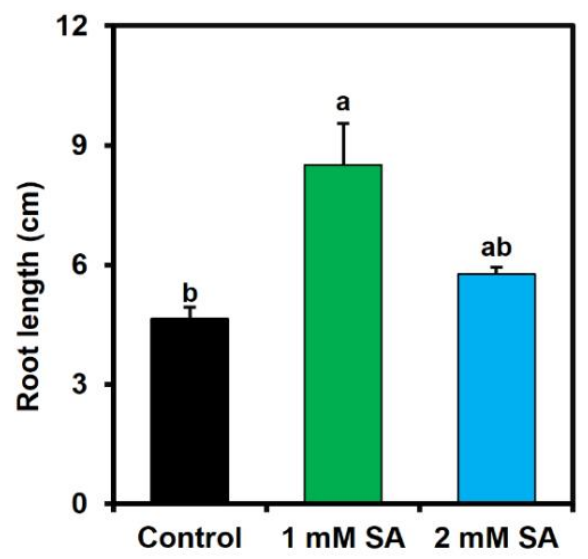

(b)

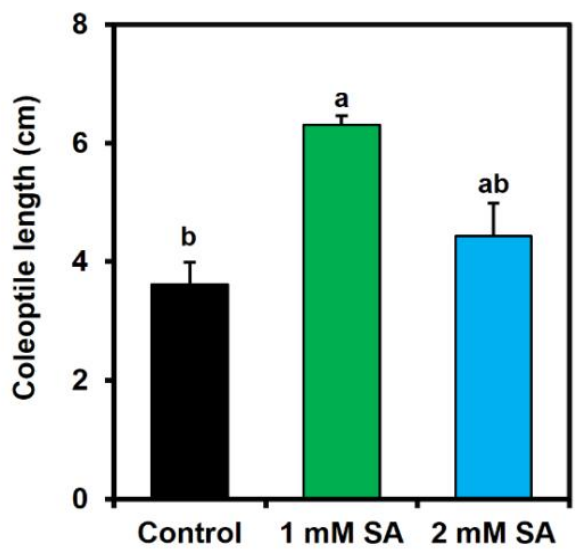

(d)

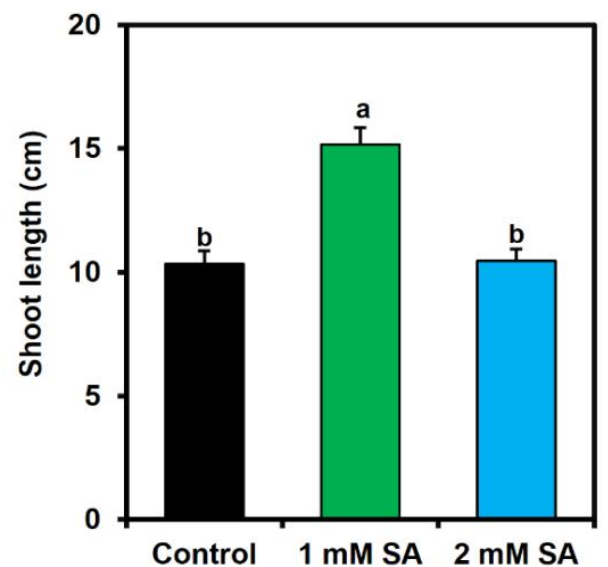

(f)

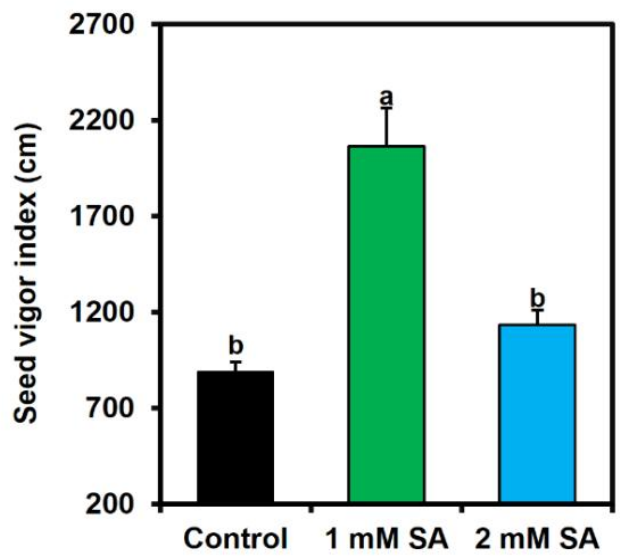

Figure 1 Effects of seed priming with SA on okra seed germination (a), coleoptile length (b), coleoptile weight (c), shoot length (d), root length (e), and seed vigor index (f).The error bar represents standard error. Differences among treatments were analyzed by Tukey's test: $\mathrm{P}<0.05$. 
3.2 Supplementation of SA regulates the relative water content and leaf pigments of okra

This study investigated the water status of okra plants by measuring relative water content (RWC) with or without SA. Supplementation of $1 \mathrm{mM}$ and $2 \mathrm{mM} \mathrm{SA}$ increased RWC 13.9 and $21 \%$, respectively, compared with control (Figure 2a).

(a)

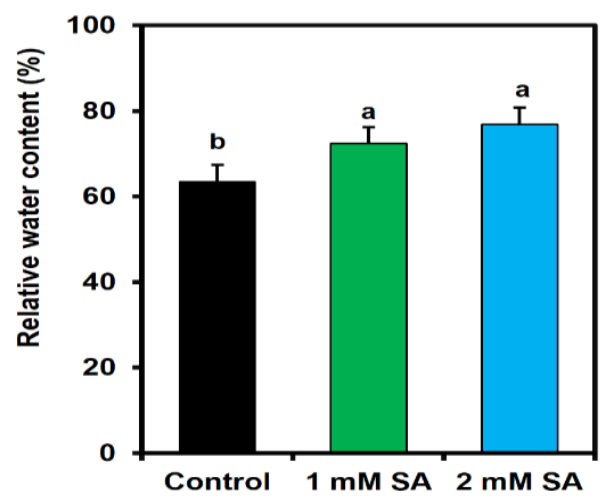

(c)

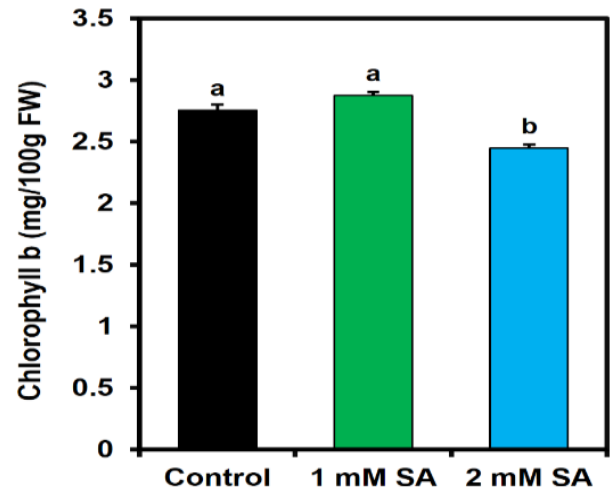

Results of pigment analysis revealed that there were no significant differences in Chl $a$ and $C h l b$ content with or without $1 \mathrm{mM} \mathrm{SA}$ application. However, they exhibited an increasing trend of Chl a (2.7\%), Chl b (4.3\%), and total chlorophyll (3.7\%) while carotenoids contents did not affect that concentration of SA compared with control (Figure $2 \mathrm{~b}-\mathrm{e}$ ). On the other hand, $2 \mathrm{mM}$ SA reduced the Chla, Chl b, total chlorophyll, and carotenoids contents compared with control (Figure 2b-e).

(b)

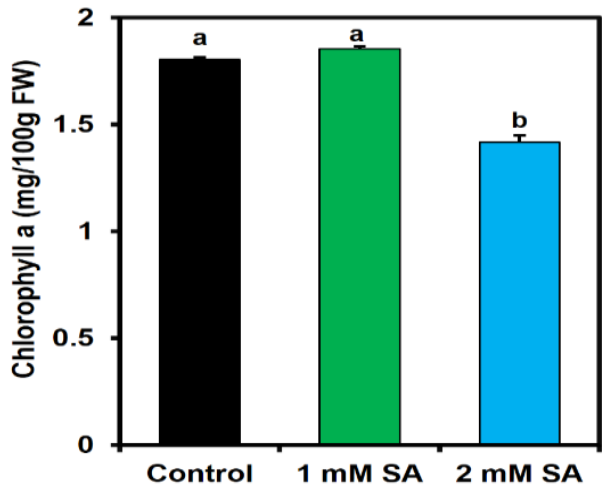

(d)

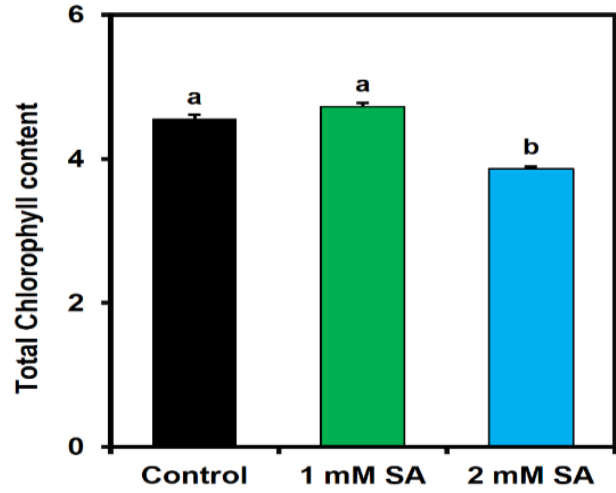

(e)

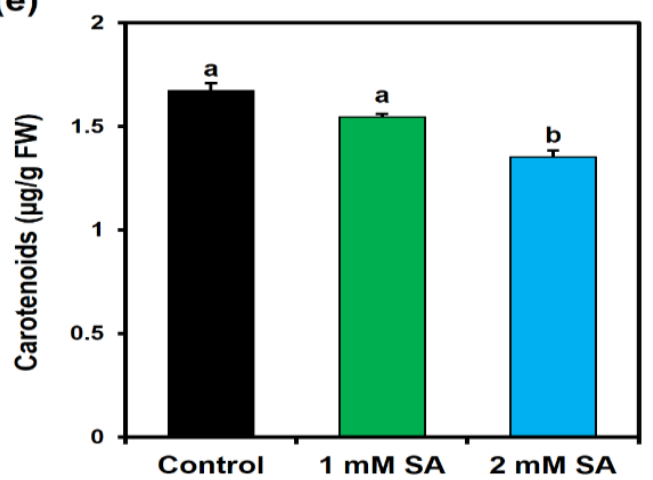

Figure 2 Effects exogenous application of SA on relative water content (a), chlorophyll contents (b-d), and carotenoids (e) of okra plant. The error bar represents standard error. Differences among treatments were analyzed by Tukey's test: $\mathrm{P}<0.05$. 
3.3 Exogenous SA regulates photosynthetic parameters of okra plant

The present study investigated the effects of exogenous SA on photosynthetic parameters such Pn, Tr, Gs, and WUE of okra plants. The results showed a significant reduction in Pn $(28.09 \%)$, $\operatorname{Tr}(26.07 \%)$, and Gs $(48.57 \%)$ with the application of $2 \mathrm{mM} \mathrm{SA}$ compared with control (Figure 3a-c). On the other hand, supplementation of $1 \mathrm{mM} \mathrm{SA}$ did not show any effect on Pn, and Tr compared with control (Figure 3a, b). However, the Gs (28.57\%) and WUE (27.3\%) showed a reduction with $1 \mathrm{mM} \mathrm{SA}$ application while $2 \mathrm{mM}$ SA application did not change WUE compared with control (Figure 3c-d). These results indicate that supplementation of different concentrations of SA acid regulates the photosynthetic parameters of okra.

3.4 The SA enhances plant growth, yield contributing characters, and yield of okra

This study examined the effects of exogenous SA application on the growth of okra plants. The results showed that application of 1 mM SA significantly increased $70.9 \%$ plant height $(31.3 \mathrm{~cm})$ while (a)

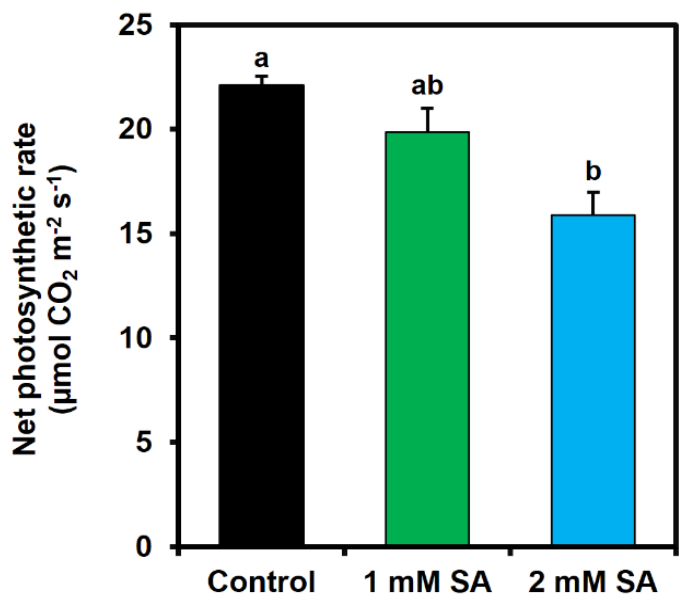

(c)

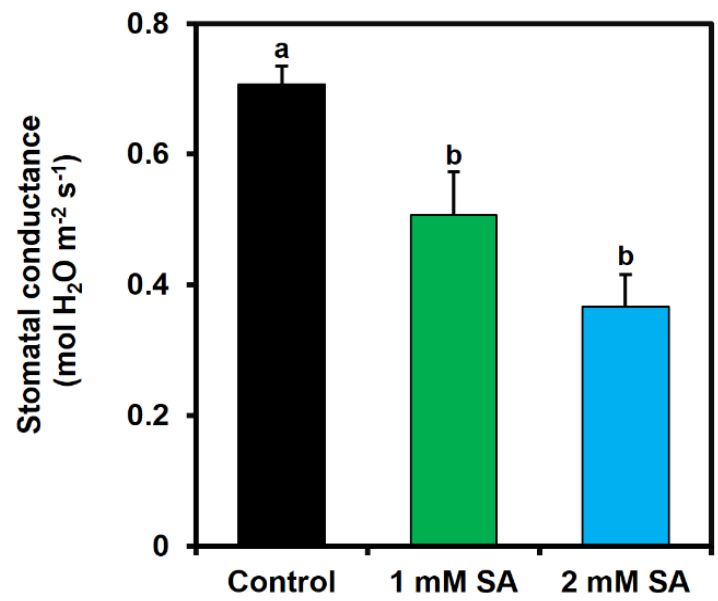

(b)

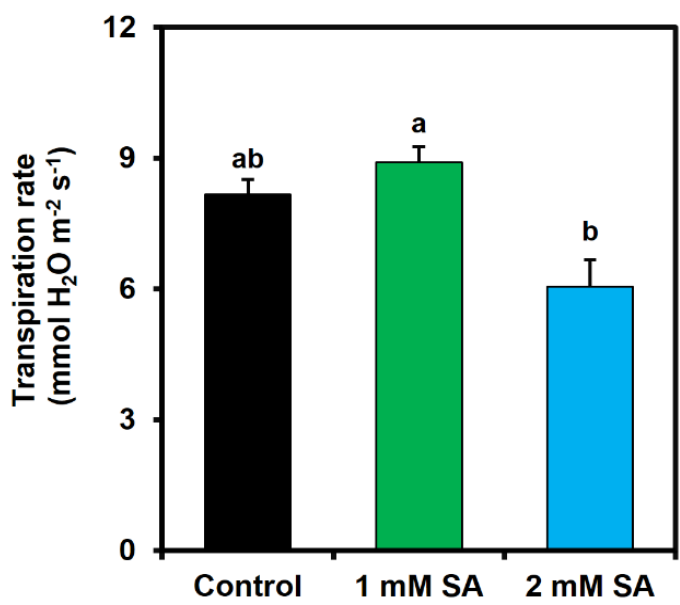

(d)

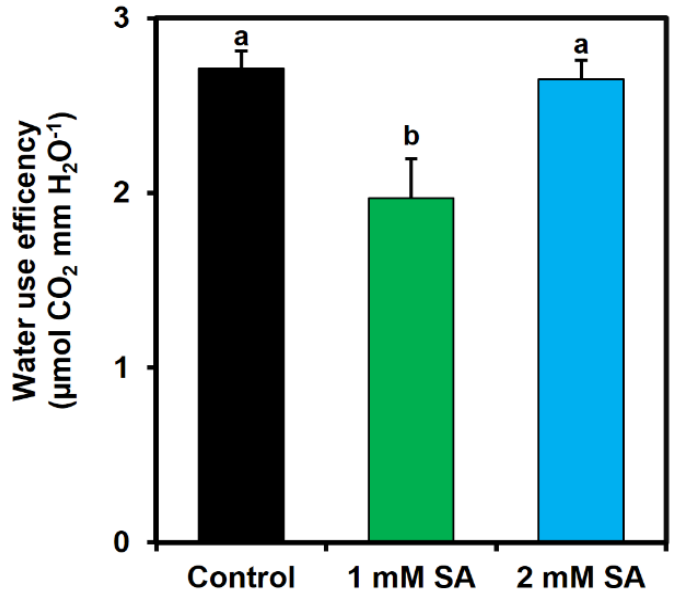

Figure 3 Effects exogenous application of SA on net photosynthetic rate (a), transpiration rate (b), stomatal conductance (c), and water use efficiency (d) of okra plant. The error bar represents standard error. Differences among treatments were analyzed by Tukey's test: $\mathrm{P}<0.05$. 
$2 \mathrm{mM}$ of SA $(20.6 \mathrm{~cm})$ did not show any significant increases in plant height as compared to the control $(18.3 \mathrm{~cm})$ (Figure $4 \mathrm{a})$. Similarly, supplementation of $1 \mathrm{mM} \mathrm{SA}$ reduced the duration of flower bud initiation and the days to first flowering compared to 2 mM SA and control (Figure 4b, c). It has been observed that first flower bud initiation and days to first flowering were observed at 49.67 days and 53.67 days, respectively at $1 \mathrm{mM}$ SA supplementation. A similar trend was reported in the case of final yield, the highest number of fruits per plant (32.6) was found in the case of $1 \mathrm{mM}$ SA supplementation compared with control (24.6) and 2 mM SA (23.6) (Figure 4d).

3.5 Estimate the treatment-variables interactions through PCA

The PCA was performed to assess the relationship between the morpho-physiological traits and SA treatments (Figure 5). PC scores separated three treatments for their positive and negative values across PC1 and PC2 (Figure 5). The PC1 and PC2 conjointly exhibited $81.2 \%$ of the data variability among the morpho-physiological traits of okra. PC1 exhibited $48.9 \%$ data variability and separated $1.0 \mathrm{mM}$ SA treatment from the other two treatments (control and $2.0 \mathrm{mM} \mathrm{SA}$ ) for their positive and negative PC scores, respectively (Figure 5). PC1 separated $1.0 \mathrm{mM}$ SA treatment from the two other treatments due to higher positive coefficients of GP, CL, CW, SL, RL, SVI, plant height, number of fruits per plants, RWC, transpiration rate, and contents $\mathrm{Chl}$ a, Chl b, total Chl (Figure 5). The PCA2 exhibited $32.3 \%$ data variability and this PC separated the control treatment from the $2.0 \mathrm{mM} \mathrm{SA}$ treatment largely due to higher negative coefficients of stomatal conductance (Gs) and net photosynthetic rate (Pn) (Figure 5). (a)

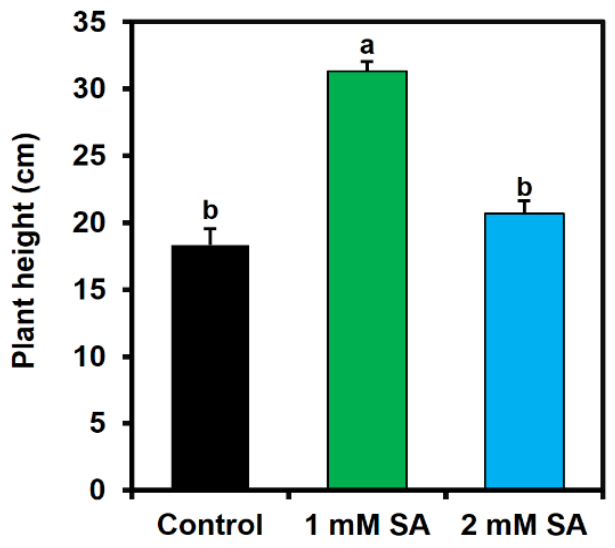

(c)

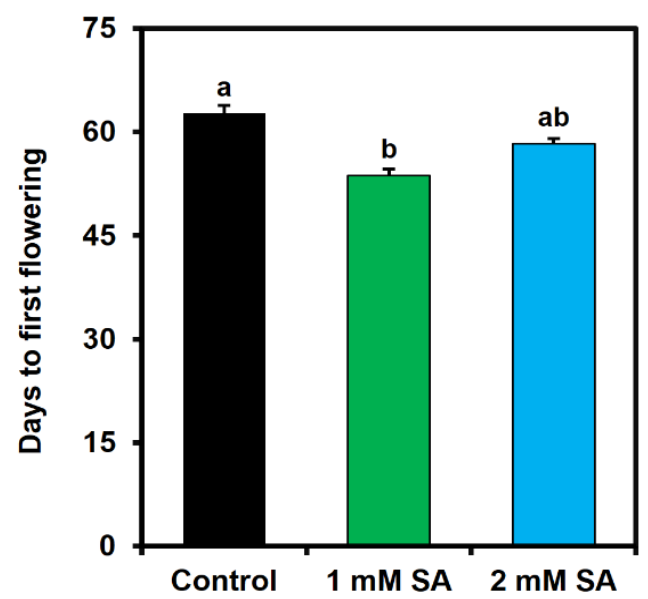

(b)

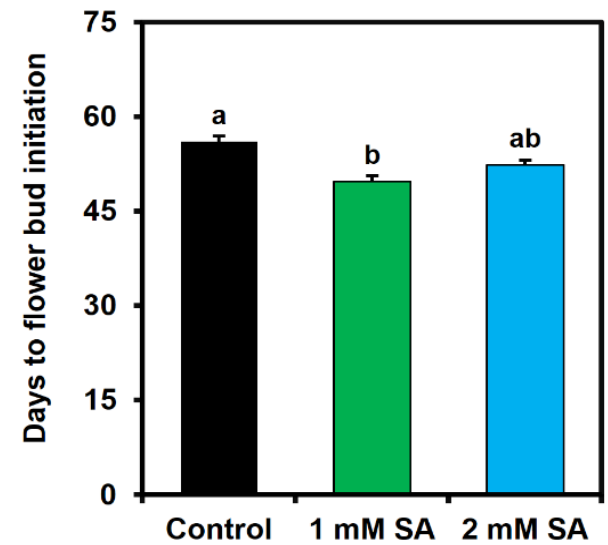

(d)

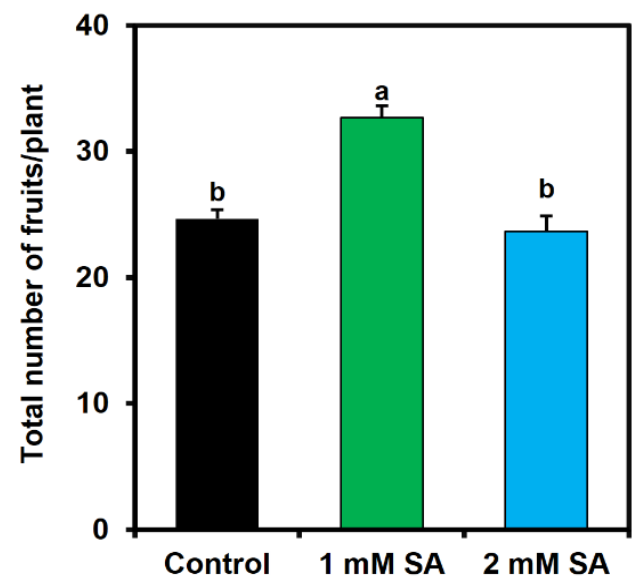

Figure 4 Effects exogenous application of SA on plant height, yield and yield contributing characters of okra. (a) Plant height (b) Days to flower bud initiation (c) Days to first flowering (d) total number of fruits/plants. The error bar represents standard error. Differences among treatments were analyzed by Tukey's test: $\mathrm{P}<0.05$. 


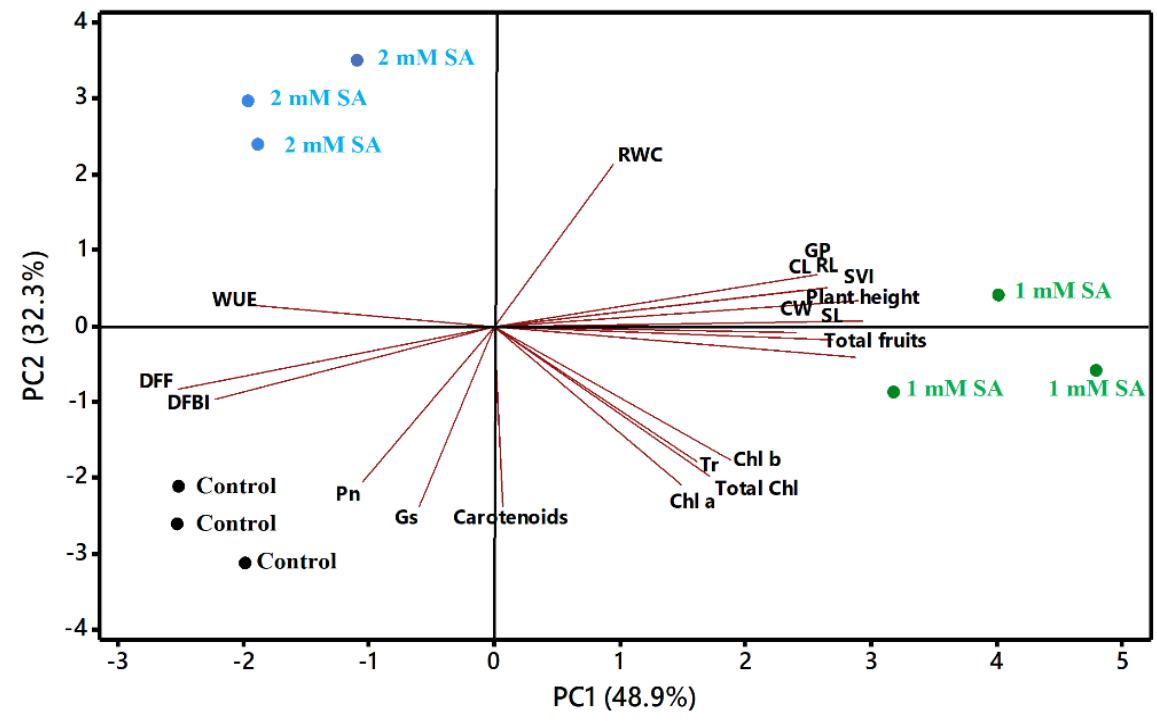

Figure 5 Principal component analysis of morpho-physiological parameters of okra. The studied parameters were germination percentage (GP), coleoptile length (CL), coleoptile weight (CW), shoot length (SL), root length (RL), seed vigor index (SVI), plant height, Chl a, Chl b, total Chl, carotenoids, net photosynthetic rate (Pn), transpiration rate ( $\mathrm{Tr}$ ), stomatal conductance (Gs), water use efficiency (WUE), days to flower bud initiation (DFBI), days to first flowering (DFF), and fruits per plant.

\section{Discussion}

It is well-known that proper germination of the seed is the fundamental and crucial step in the plant development cycle, as it plays an important role in the acclimatization of seedlings to the ever-changing environment and its subsequent productivity (Sonya et al., 2019; Shiade \& Boelt, 2020). In this era, different pretreatment application techniques are widely being used on the emergence and establishment of seedlings. Seed priming is one of the most widely used techniques that promote seed germination, enhance morphological parameters, and improve plant growth and development under non-stress as well as in stress conditions (Muhei, 2018; Rhaman et al., 2020, 2021a). Therefore, the present study was conducted on the evaluation of the effects of seed priming and exogenous application SA on the okra plant. Many studies reported that okra seed priming enhances germination and SVI (Hussein 2015; Tania et al., 2020; Lamichhane et al., 2021). Results of the current study showed that okra seed priming with 1 mM SA significantly increased GP, CL, CW, SL, RL, and SVI (Figure 1), while $2 \mathrm{mM} \mathrm{SA}$ did not show any significant change in the germination rate and seedling traits. The PCA analysis also revealed that the majority of morpho-physiological traits were closely associated with $1 \mathrm{mM}$ SA treatment (Figure 5). These results indicated that a lower concentration of $1 \mathrm{mM} \mathrm{SA}$ is more effective than a higher concentration of $2 \mathrm{mM}$ SA on the enhancement of seed germination and seedling traits of okra.

Being a water related trait, RWC is a well-known pointer of water status in plants (Li et al., 2017). It has been reported that supplementation of different exogenous chemicals enhances the water status of different plant species under stress and normal conditions (Saboon et al. 2015; Ahmad et al. 2017; Tahjib-Ul-Arif et al. 2018). Results of this study also showed that supplementation of SA significantly increased RWC in plants (Figure 2a) and indicates that SA may be involved in up-taking extra water from the soil to fine-tune water status inside plant tissues. Exogenous application of SA enhances leaf pigments in B.napus, wheat, and maize (Baghai et al., 2002; Tahjib-Ul-Arif et al., 2018; Sumaiya et al., 2020). We found that supplementation of $1 \mathrm{mM} \mathrm{SA}$ significantly increased $C h l a$, Chl b, Total chlorophyll contents, and carotenoids of okra leaves. On the contrary, supplementation of $2 \mathrm{mM}$ SA reduced the leaf pigments (Figure $2 b-e$ ). These results indicated that a lower concentration of SA may enhance the activities of enzymes related to pigments biosynthesis and/or reduce the oxidative stress which reduces the degradation of leaf pigments. On the other hand, a high concentration of SA may inhibit the biosynthetic enzymes of leaf pigments and/or enhance the oxidative stress which may decline the leaf pigments status (Moharekar et al., 2003; Janda et al., 2014; Ma et al., 2017).

Enhancement of photosynthesis capacity is a crucial step for successful crop production as photosynthetic attributes are the primary determinant of crop yield (Simkin et al., 2019). Plant regulates photosynthetic attributes including Gs, and $\mathrm{Tr}$ to enhance photosynthetic capacity (Nazar et al., 2015; Maswada et al., 2018). In the present study, supplementation of $2 \mathrm{mM}$ SA decreased the photosynthetic efficiency which may be associated with decreased $\operatorname{Tr}$ and Gs (Figure 3b, c). Similar results have been reported by 


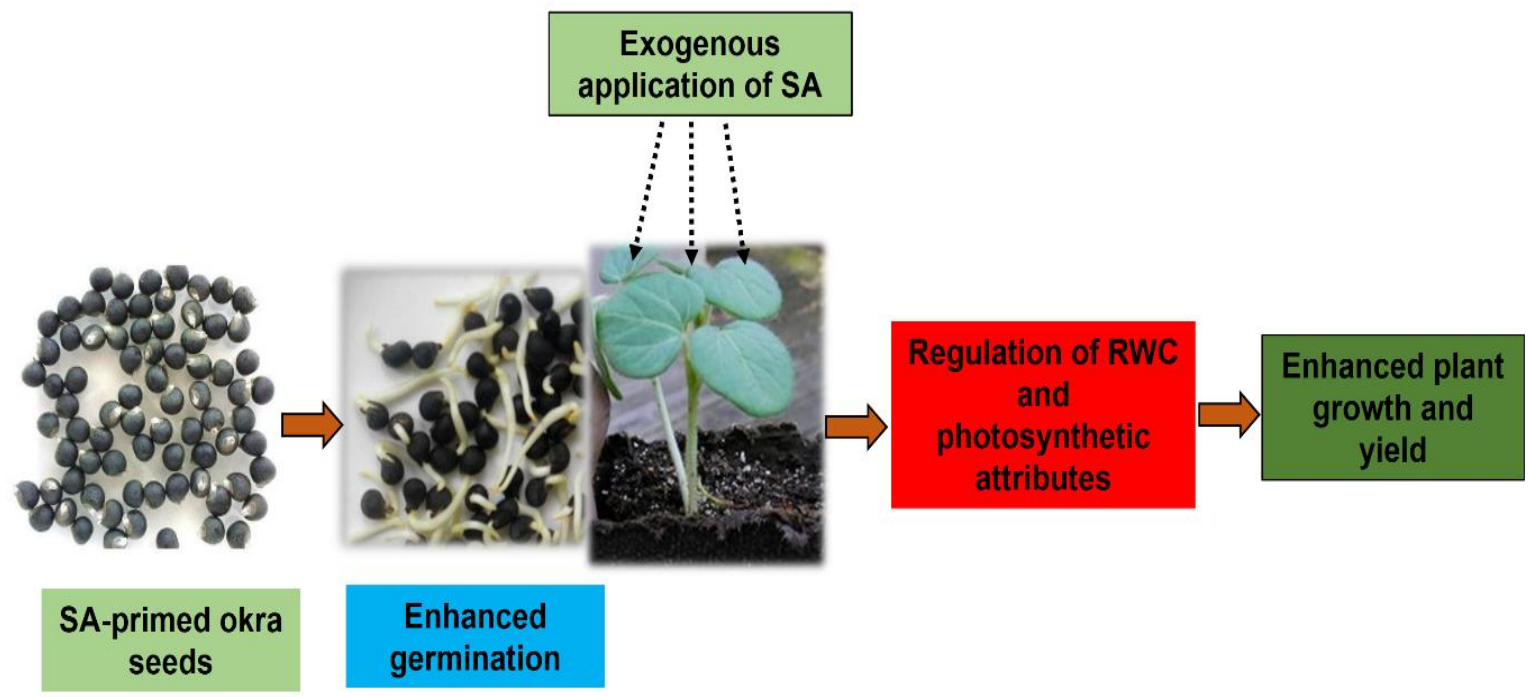

Figure 6 Simplified model showing SA-regulated okra crop enhancement by seed priming and exogenous application of SA.

various previous researchers and suggested that reduced photosynthetic efficiency might be associated with decreased photosynthetic attributes (Maswada et al., 2018; Tahjib-Ul-Arif et al., 2018). Moreover, supplementation of $1 \mathrm{mM}$ SA did not change the Pn and Tr but that supplementation reduced the Gs and WUE (Figure 3c, d). These results indicated that a low concentration of SA induces stomatal closure (Prodhan et al., 2018) and reduces WUE, which may help to enhance RWC (Figure 2a) for the physiological function of plants.

Among various physiological processes, photosynthetic attributes are directly related to crop production. In the present study, supplementation of $1 \mathrm{mM}$ SA significantly enhanced leaf pigments (Figure 2b-e) and regulated Pn, Tr, Gs, and WUE (Figure 3). Thus, low concentration of SA contributed to improved seedling traits (Figure 1), increased plant height, reduced time duration on flower bud initiation and days to first flowering, and increased number of fruits per plant (Figure $4 \mathrm{a}-\mathrm{d}$ ) by regulating photosynthetic attributes. On the other hand, a high concentration of SA reduced the germination and seedling traits (Figure 1) and the number of fruits per plant by degrading the photosynthetic attributes. The PCA analysis also strengthen that supplementation of $1 \mathrm{mM} \mathrm{SA}$ enhanced the morpho-physiological parameters of okra (Figure 5). Taken together with all the results in the study, we proposed a simple model for the SA-regulated okra crop enhancement by seed priming and exogenous application of SA (Figure 6). Our results are in agreement with previous reports where seed priming and exogenous application of SA enhance seed germination and productivity of okra by regulating RWC and photosynthetic attributes (Rhaman et al., 2021a).

\section{Conclusion}

It is concluded that seed priming and exogenous application of SA enhance okra seed germination and productivity by regulating leaf water contents, leaf pigments, and photosynthetic attributes. Further, the results of the current study also suggest that $1 \mathrm{mM} \mathrm{SA}$ can be used for successful okra production. However, it is highly recommended to experiment with the field level to validate the results of the current study.

\section{Conflict of interest}

The authors declare that they have no conflict of interest.

\section{References}

Abdel Latef AA, Tahjib-Ul-Arif M, Rhaman MS (2021) Exogenous auxin-mediated salt stress alleviation in faba bean (Vicia faba L.). Agronomy 11: 547.

Ahmad F, Singh A, Kamal A (2017) Ameliorative effect of salicylic acid in salinity stressed Pisum sativum by improving growth parameters, activating photosynthesis and enhancing antioxidant defense system. Bioscience Biotechnology Research Communications 10:481-489.

Baghai N, Setia RC, Setia N (2002) Effects of paclobutrazol and salicylic acid on chlorophyll content, hill activity and yield components in Brassica napus L.(cv. GSL-1). Phytomorphology 52:83-87. 
Bhasker P, Gupta PK, Sharma HP (2020) Role of Salicylic Acid on Growth, Yield, Quality and Disease Pest Reaction of Onion (Allium CepaL.) CV. Agrifound Light Red. SAARC Journal of Agriculture 18:39-49.

Dugogi EH, Mahdi NK, Matroud SAK (2012) Response of Indian mustard (Brassica juncea L.) to the distance of planting and spraying with salicylic acid and their effect on growth, seed yield and hard oil. In: Second Scientific Conference of the Faculty of Agriculture, University of Karbala, The Republic of Iraq.

Elkhalifa AE, Alshammari E, Adnan M, Alcantara JC, Awadelkareem AM, Eltoum NE, Mehmood K, Panda BP, Ashraf SA (2021) Okra (Abelmoschus Esculentus) as a Potential Dietary Medicine with Nutraceutical Importance for Sustainable Health Applications. Molecules 26:696.

Felipe VP, Antonio AL, Francisco AP (2010) Improvement of Okra (Abelmoschus esculentus L.) Hard seedness by using microelements Fertilizer. Horticultura Brasileira 28:232-235.

Gemede HF, Ratta N, Haki GD, Woldegiorgis AZ, Beyene F (2015) Nutritional Quality and Health Benefits of Okra (Abelmoschus esculentus): A Review. Journal of Food Process Technology 6(458):2.

Gul F, Arfan M, Shahbaz M, Basra S (2020) Salicylic acid seed priming modulates morphology, nutrient relations and photosynthetic attributes of wheat grown under cadmium stress. International Journal of Agriculture and Biology 23:197-204.

Hasanuzzaman M, Fotopoulos V (Eds.) (2019) Priming and Pretreatment of Seeds and Seedlings: implication in plant stress tolerance and enhancing productivity in crop plants. Springer Nature Singapore Pte Ltd, Singapore.

Hussein HJ (2015) Effect of seed priming treatment with salicylic acid on viability of okra (Abelmoschus esculentus L.) seeds. Euphrates Journal of Agriculture Science 7:1-9.

Hussein HJ (2017) The Effect of Seed Priming with Salicylic Acid and Ascorbic Acid on Viability of Local Okra (Abelmoschus esculentus L.) Seeds Stored for Three Years. Journal of Global Pharma Technology 8(9): 110-115.

Janda T, Gondor OK, Yordanova R, Szalai G, Pál M (2014) Salicylic acid and photosynthesis: signalling and effects. Acta Physiological Plant 36:2537-2546.

Khan W, Prithiviraj B, Smith DL (2003) Photosynthetic responses of corn and soybean to foliar application of salicylates. Journal of Plant Physiology 160:485-492.
Koo YM, Heo AY, Choi HW (2020) Salicylic acid as a safe plant protector and growth regulator. Plant Pathology Journal 36:1-10.

Kusvuran S (2012) Influence of drought stress on growth, ion accumulation and antioxidative enzymes in okra genotypes. International Journal of Agriculture and Biology 14:401-406.

Lamichhane A, Mamata KC, Manisha Shrestha, Binaya Baral (2021) Effect of Seed Priming on Germination of Okra (Abelmoschus esculentus var. ArkaAnamika). Malaysian Journal of Sustainable Agriculture 5:111-114.

Li Y, Li H, Li Y, Zhang S (2017) Improving water-use efficiency by decreasing stomatal conductance and transpiration rate to maintain higher ear photosynthetic rate in drought-resistant wheat. Journal of Crop Science 5:231-239.

Lichtenthaler HK (1987) Chlorophylls and carotenoids: pigments of photosynthetic bio-membranes. Methods Enzymology 148:350382.

Ma X, Zheng J, Zhang X, Hu Q, Qian R (2017) Salicylic acid alleviates the adverse effects of salt stress on Dianthus superbus (Caryophyllaceae) by activating photosynthesis, protecting morphological structure, and enhancing the antioxidant system. Frontiers in Plant Science. 8:600. doi: 10.3389/fpls.2017.00600.

Maswada HF, Djanaguiraman M, Prasad PVV (2018) Response of photosynthetic performance, water relations and osmotic adjustment to salinity acclimation in two wheat cultivars. Acta Physiological Plant 40:1-15.

Moharekar ST, Lokhande SD, Hara T, Tanaka R, Tanaka A, Chavan PD (2003) Effect of salicylic acid on chlorophyll and carotenoid contents of wheat and moong seedlings. Photosynthetica 41:315-317.

Mostofa MG, Fujita M (2013) Salicylic acid alleviates copper toxicity in rice (Oryza sativa L.) seedlings by up-regulating antioxidative and glyoxalase systems. Ecotoxicology 22:959-973.

Muhei SH (2018) Seed priming with phytohormones to improve germination under dormant and abiotic stress conditions. Advanced Crop Science Technology 6:403-409.

Najafian S, Khoshkhui M, Vahid T (2009) Effect of salicylic acid and salinity in rosemary (Rosmarinus officinalis L.): Investigation on changes in gas exchange, water relations, and membrane stabilization. Advanced Environmental Biology 3:322-328.

Nazar R, Umar S, Khan NA, Sareer O (2015) Salicylic acid supplementation improves photosynthesis and growth in mustard through changes in proline accumulation and ethylene formation under drought stress. South Africa Journal of Botany 98:84-94. 
Pandita VK, Anand A, Nagarajan S, Seth R, Sinha SN (2010) Solid matrix priming improves seed emergence and crop performance in okra. Plant Physiology 38:665-674.

Prodhan MY, Munemasa S, Nahar MN, Nakamura Y, Murata Y (2018) Guard cell salicylic acid signaling is integrated into abscisic acid signaling via the $\mathrm{Ca} 2+/ \mathrm{CPK}-d e p e n d e n t$ pathway. Plant Physiology 178:441-450.

Rahman IU, Ali S, Alam M, Basir A, Adnan M, Malik MFA, Shah AS, Ibrahim M (2016) Effect of seed priming on germination performance and yield of okra (Abelmoschus esculentus L.) Pakistan Journal of Agricultural Research 29:250-259.

Raza SH, Shafiq F, Khan I (2013) Seed invigoration with water, ascorbic and salicylic acid stimulates development and biochemical characters of okra (Ablemoschus esculentus) under normal and saline conditions. International Journal of Agriculture and Biology 15:486-492.

Razmi N, Ebadi A, Daneshian J, Jahanbakhsh S (2017). Salicylic acid induced changes on antioxidant capacity, pigments and grain yield of soybean genotypes in water deficit condition. Journal of Plant Interaction 12:457-64.

Rhaman MS, Imran S, Karim MM, Chakrobortty J, Mahamud MA, Sarker P, Tahjib-Ul-Arif M, Robin AH, Ye W, Murata Y, Hasanuzzaman M (2021b) 5-aminolevulinic acid-mediated plant adaptive responses to abiotic stress. Plant Cell Reports 10:1-9.

Rhaman MS, Imran S, Rauf F, Khatun M, Baskin CC, Murata Y, Hasanuzzaman M (2021a) Seed Priming with Phytohormones: An Effective Approach for the Mitigation of Abiotic Stress. Plants 10:37.

Rhaman MS, Kibria MG, Hossain M, Hoque MA (2016) Effects of organic manure and bio-slurries with chemical fertilizers on growth and yield of rice (cv. BRRI dhan28). International Journal of Experimental Agriculture 6: 36-42.

Rhaman MS, Rauf F, Tania SS, Khatun M (2020) Seed priming methods: Application in field crops and future perspectives. Asian Journal of Research and Crop Science 5: 8-19.

Saboon RI, Ahmad N, Ilyas N, Batool N, Gul S (2015) Salicylic acid enhances wheat plant growth under water stress conditions.
International Journal of Biology and Biotechnology 12:329-336.

Shiade SR, Boelt B (2020) Seed germination and seedling growth parameters in nine tall fescue varieties under salinity stress. Acta Agriculturae Scandinavica, Section B-Soil \& Plant Science 17:485-94.

Simkin AJ, López-Calcagno PE, Raines CA (2019) Feeding the world: improving photosynthetic efficiency for sustainable crop production. Journal of Experimental Botany 70:1119-1140.

Sonya A, Md TU, Sakil MA, Sohag AA, Polash MA, Hossain MA (2019) Hydrogen peroxide priming alleviates chilling stress in rice (Oryza sativa L.) by enhancing oxidant scavenging capacity.

Fundamental and Applied Agriculture 4(1):713-722.

Sumaiya F, Rasel M, Tahjib-Ul-Arif M, Al-Galib MA, Sarker KK, Hossain MA (2020) Exogenous salicylic acid and thiourea ameliorate salt stress in wheat by enhancing photosynthetic attributes and antioxidant defense. Journal of Bangladesh Agricultural University 18:272-282.

Tahjib-Ul-Arif M, Siddiqui MN, Sohag AA, Sakil MA, Rahman MM, Polash MA, Mostofa MG, Tran LS (2018) Salicylic acidmediated enhancement of photosynthesis attributes and antioxidant capacity contributes to yield improvement of maize plants under salt stress. Journal of Plant Growth Regulation 37:1318-1330.

Tahjib-Ul-Arif M, Zahan M, Karim M, Imran S, Hunter CT, Islam M, Mia M, Hannan M, Rhaman MS, Hossain M, Brestic M (2021) Citric acid-mediated abiotic stress tolerance in plants. International Journal of Molecular Sciences 22: 7235.

Tania SS, Rhaman MS, Hossain MM (2020) Hydro-priming and halo-priming improve seed germination, yield and yield contributing characters of okra (Abelmoschus esculentus L.). Tropical Plant Research 7: 86-93.

Vwioko ED (2013) Performance of soybean (Glycine max L.) in salt-treated soil environment following salicylic acid mitigation. NISEB Journal 13:44-49.

Yakoubi F, Babou FZ, Belkhodja M (2019) Effects of Gibberellic and Abscisic Acids on Germination and Seedling Growth of Okra (Abelmoschus esculentus L.) under Salt Stress. Pertanika Journal of Tropical Agricultural Science 42:847-860. 